\title{
United Nation Convention on the Law of the Sea: Inevitable Way towards Revision to Overcome South China Sea Disputes
}

\author{
Natalia Prisekina ${ }^{1} \&$ Roman Dremliuga $^{1}$ \\ ${ }^{1}$ School of Law, Far Eastern Federal University, Vladivostok, Russia \\ Correspondence: Roman Dremliuga, School of Law, Far Eastern Federal Unversity, Vladivostok, Russia. E-mail: \\ dremliuga.ri@dvfu.ru
}

Received: March 9, 2015 Accepted: March 25, 2015 Online Published: June 5, 2015

doi:10.5539/ass.v11n18p274 URL: http://dx.doi.org/10.5539/ass.v11n18p274

\begin{abstract}
In the authors' opinions, some provisions and definitions of UNCLOS have serious gaps that lead to various interpretations and misunderstandings by countries. Due to provisional gaps, all parties of the South China Sea Disputes have their own opinions on the UNCLOS interpretations and are confident that they follow International Law. The authors propose that certain provisions of UNCLOS need revised in order to resolve actual disputes and prevent further debates. These provisions include, but are not limited to, the current distinction between an island and a rock; and the strait baseline concept that permits to delineate big sea areas far from the coast.
\end{abstract}

Keywords: South China Sea, United Nations Convention on the Law of the Sea, Paracel Islands, Spratly Islands, Rocks, Islands, Baselines

\section{Introduction}

It has been over 20 years since the implementation of the United Nations Convention on the Law of the Sea (hereinafter - UNCLOS). Elaboration of this treaty was a significant step to the settlement of numerous international territorial disputes concerning the law of the sea around the world. However, some disputes are still in progress. In the authors' opinions, some provisions and definitions of UNCLOS have serious gaps that lead to various interpretations and misunderstandings by countries. Among all of the shifting of focal points in economics and politics in the Asia Pacific Rim, the most "hot" topic concerning UN Convention on the law of the sea is Dispute in the South China Sea. This affects not only Littoral Southeast Asian States involved in the Dispute, but even key regional players with no claims in the dispute, such as: India, Japan and the United States (US). Each of those state actors are increasingly connected (Chan \& Li, 2015), moreover all claimants to the SCS are increasing their military capabilities (Majumdar, 2015).

Due to provisional gaps, all parties of the South China Sea Dispute (Brunei, China, Malaysia, the Philippines, and Vietnam) have their own opinions on the UNCLOS interpretations and are confident that they follow International Law. The Authors consider that certain provisions of UNCLOS should be revised in order to resolve actual disputes and prevent further debates.

\section{2. "Island" or "Rock" Issue}

The first issue of importance is the current distinction between an island and a rock. This issue is significant since according to UNCLOS Article 121, all maritime zones such as the territorial, the contiguous, the exclusive economic, and the continental shelf of an island are held to the same standards as other land territory. However, Rocks which are not able to support "human habitation" or "economic life" of their own cannot have exclusive economic zone or continental shelf. This applies to Russia, which has many islands in the Arctic that probably are not so sustainable for habitation or economic life such as small rocks and atolls in the Pacific Ocean. Also, it should be noted that modern technologies could provide possibilities for creation of appropriate conditions for habitation and economic activity everywhere. Yearly, the significance of this issue is increasingly important due to the growth of mineral ocean resources.

In the practice of sea disputes, some countries use the term "island" in a very common sense. For instance, Japan, in case of, "Okinotorishima", and China uses the term "qundao" to name all land pieces enclosed by water, regardless of their size and other characteristics. This definition even includes some islands permanently situated 
under water, such as Macclesfield Bank situated in the Southern China Sea in the four archipelagos. The Spratly Islands in Chinese are called Nansha Archipelago. This definition of an "island" under the UNCLOS leaves space for further debate, discussion, and allows for states use their interpretation of this term.

Specifically, it leads to the situation that almost all of claimants in the South China Sea attempting to establish their sovereignty claims by occupying certain islands and reefs. Claimants construct airstrips, research stations, platforms, tourist attractions, and military facilities on them to show that they have a real island that produces an exclusive economic zone and continental shelf. For instance, the largest islands are occupied by Vietnam and the Philippines. Vietnam, the Philippines, China and Malaysia occupied from 5 to 21 features. All of those countries claim that they have rights to delimitate an exclusive economic zone and continental shelf around a small piece of land that did not originally sustain human habitation. Some scholars proclaim that less than 50 of near 150 features in the South China Sea are islands as defined in Article 121 of UNCLOS. Those features are defined as islands since they are naturally formed areas of land above water at high tide. In fact the majority of the 50 or so islands in the South China Sea are diminutive. Therefore those formations should be considered as rocks which cannot sustain human habitation or economic life of their own (Beckman, 2011). Some other authors provide the similar evaluation about number of rocks which could be definitely recognized as rocks (Kuok, 2014). At least it is extremely doubtful that all land formations in the South China Sea could have their own Exclusive Economic Zone (Zou, 2005). In any case, States should prove that it occupies an "island", not a "rock", because all other parties do not recognize the right to delimitate based on so diminutive features.

For example, in its response to Chinese claims, especially the map with the U-shaped line, Indonesia made clear its opinion that "those remote or very small features in the South China Sea isn't worth an exclusive economic zone or continental shelf of their own" (Song \& Tønnesson, 2013). The above example highlights Indonesia's opposite view on perception of Article 121 of UNCLOS. Only Taiwan occupied island with natural source of water, majority of all others is enough to put flag.

For nearly 30 years after United Nations Convention on the law of the sea was negotiated, International law provided little guidance on how to interpret this clause. However, in 2009, the United Nations International Court of Justice examined the case of sea delimitation between Ukraine and Romania. The most significant part of this dispute was the determination of the legal nature of Snake Island, a small island in the Black Sea, which has pretty rocky coast. It is near 0.2 square $\mathrm{km}$ and is more than 40 meters above sea level at its highest point. Snake Island has such facilities as a lighthouse and small peer, but little fresh water or vegetation. A little number of military and research personnel are stationed there (similar situation with the Spratly Islands in the South China Sea), it requires regular resupply of food, water and other necessities from the mainland in order to sustain personnel on Snake Island. The United Nations International Court of Justice proclaimed that Snake Island did not produce an exclusive economic zone or a continental shelf and did not significantly make different the maritime borderline between mentioned countries.

Despite that ruling, some countries try to generate an exclusive economic zone and continental shelf by using small rocks. Since decisions of the UN International Court of Justice does not create rules and charge obligations, only to the parties of a particular dispute. In addition, there is no obligation to submit any dispute to the UN International Court of Justice and most of politically strong countries choose different ways.

The characteristic of sustainability for human habitation and economic life are hard to measure, due to the subjective application of these definitions. In context with the development of technology, ocean features that previously were not capable of sustaining human habitation or did not have economic life, are now increasingly able to create these capabilities (Dong, 2005). From this point of view, we propose revising the article in three ways.

First, exclusion of small areas of land which are not defined as islands and produce EEZ and continental shelves by formal criteria as stated in UNCLOS with length of territorial sea and EEZ. It should be defined in meters or in other fixed units in order to avoid further disputes. For example, the transparent definition of maximum length of breadth of the territorial sea which is limited by 12 nautical miles, measured from baselines, helps to decrease any disputes in this sphere. Although some scholars consider that size, in itself not decisive, and an island of a certain size may be a rock. The rock formation may be able to sustain human habitation or economic life of its own (Elferink, 2001). A set measurement of minimal size of an island would exclude some actual islands from this category, but leads to transparency in this sphere.

Second provision, includes a list of natural features of an island that sustains human life. Those features include: natural sources of water on the island, sources of food or soil characteristics. 
Third, indicators of economic life such as fishing facilities, lighthouses, some navigational buildings, and other objective evidence that proves human economic activity. According to the authors' opinions flagging is not appropriate evidence of human presence.

\section{3. "Straight Baselines" Provision}

The second problem is the strait baseline conception that permits to delineate big sea areas far from the coast. Some famous law of the sea authors predicted difficulties more than thirty years before, in 1973 Arvid Pardo said that states would try to establish their outer limits as far as possible due to "elastic interpretations of UNCLOS" (Westerman, 1988).

In accordance with Article 7 of UNCLOS in localities where the coastline is deeply indented and cut into, or if there are numerous islands close to the coast in its immediate vicinity, the method of straight baselines could be used in drawing the baseline from which the breadth of the territorial sea is marked off. However, how many nautical miles is "immediate vicinity"? Furthermore what is legal meaning of terms "deeply indented" and "cut into"? How close should the fringe of island be to coast in terms of physical values?

We have two famous examples of using strait baselines: the Norwegian Fjords and the Canadian Northwest Passage where tremendous territory is claimed as internal water because it lays within strait baselines.

It should be noted that the straight baseline method allows a country with offshore islands and/or very rough coastlines to reckon its territorial seas from straight lines drawn from a point on the coast to the islands, or from island to island. After connecting the points, the water behind the lines is recognized as internal water, while waters away from the line and towards open waters are considered territorial seas. Grounds for this concept are created by the Fisheries Case (United Kingdom vs. Norway) of 1951, it is important because it accepted the method of using straight baselines for delimitation.

It should be noted that, not only the mentioned methods could be used, but methods of applying baselines defined in court decision is commonly recognized by states. In other words, there are two main geographical contexts where the geometrical application of straight baselines may be used. The first is a deeply indented coast and the second is borderline of the archipelago coast (Pharand, 2007).

Vietnam used that ruling in its 1982 Statement on the Territorial Sea Baseline, to established straight baselines from which its territorial sea was to be measured. However, Vietnam's system of straight baselines was strongly protested by other countries on the basis that Vietnam did not meet the criteria set forth by the Article 7 of UNCLOS.

Baselines of mainland part of China are mostly based on shape of its coast. However, in few island-type locations, baselines of China encircle more than 2,500 square nautical miles of sea area, mostly in the East China Sea, and exclude this space from full international use. In the South China Sea, China has proclaimed straight baselines near the Paracel Islands. The majority of Anglo-American scholars conclude that if China defines baselines around the South China Sea islands, it would confer to itself a large part of the South China Sea with internal waters regime. This interruption is pragmatic and would violate Article 89 of the UNCLOS, which proclaims that "no state may validly purport to subject any part of the high seas to its sovereignty" (Joyner, 1999). Opinion exists that the South China Sea is located in a part of the world where normal baselines are not that normal, but are rather becoming something of an exception (Franckx \& Benata, 2011). Position of China that is not only UNCLOS is applied to define baseline but international customs and all other sources. Sometimes it mentioned as UNCLOS and related international reality (Amer, 2014).

Scholars argue that China has unilaterally applied straight baselines along its coastline. Doing so, China has established a legal basis for claiming vast areas of the sea. Many of China's State practices and regulations based on straight baselines are neither in accordance with international law, nor generally recognized as being international custom (Kim, 2013).

Following this logic obliviously, that some terms of straight baseline provisions allow states to interpret them in a different way. Such a state of affairs creates an area for numerous disputes not only in the South China Sea. For example, articles of UNCLOS that concern international straits also produce confrontation. Countries delimitate big maritime areas because the modern law of the sea allows it.

\section{Lack of Provisions to Assist in Determination of Sovereignty and Historic Title}

The third gap is that UNCLOS has no provisions which could assist in determination of sovereignty, in terms of historical claims over islands (Beckman, 2013). For example, The Chinese statement is that "China has simply been safeguarding what's rightfully her own", relied on existing historical title in comparison with other 
claimants on South China Sea island and water (Saul, 2014). Yet, in the Convention historic rights are mentioned three times "historic bays" in Article 10 and "historic title" in Article 15 and both in Article 298 and there are not any definitions or commentaries.

It is understandable that states would not sign and ratify convention that compulsory and strictly defines what means historical title on island and sea waters. Despite the ambiguity and certainty of historical title, states still make historical title claims over islands and sea waters. Vietnam and China have overlapping claims on Paracel islands based on historic title and both are confident that they follow international law (Fry \& Loja, 2014), and there are no provisions in UNCLOS to assist in a resolution.

Historical claims on sea water and island are strongly related with delimitation of sea areas. It is difficult to understand the connection of historic rights to the ratifying of the Convention. Even the use of the historic bays conception is unclear and needs additional explanations.

Another question is: what are appropriate evidences of historic title. For instance, China mostly relied on Chinese traditional maritime boundary line apparently tolerated or non-verbally submitted by the littoral and other states (Fry \& Loja, 2014). If this is rule of international law it means that, Russia and Canada in the Arctic will be able to do the same. We persistently state that UNCLOS should have regulations for resolution of historical title disputes in the sea. It is quite different to resolve this kind of disputes because in contrast with land historical title is impossible to continuously occupy and be present at sea area and on most islands.

\section{Conclusion}

In conclusion, it should be noted that UNCLOS distinctly helps to settle many disputes in the world, possibly even put a stop to some wars. Even in case of South China Sea littoral states will not resolve dispute unless mutual claims of the parties are able to comply with international law, potentially allowing for discussions on cooperation and joint development based on areas of overlapping maritime claims based on provisions of UNCLOS (Beckman \& Schofield, 2014). Everything should develop, even such useful convention as UNCLOS. That convention is not the Bible nor a dogma and it is time to revise some provisions and terms of UNCLOS, especially those that produce international conflicts. Due to the dynamic that more and more disputes by countries rely on provision of UNCLOS, it is inappropriate to have such obvious gaps and lacunas. Difficulties will arise during the negotiation of new guidelines, but it is time for revisions.

\section{References}

Amer, R. (2014). China, Vietnam, and the South China Sea: Disputes and Dispute Management. Ocean Development \& International Law, 45(1), 17-40. http://dx.doi.org/10.1080/00908320.2013.839160

Beckman, R. (2011). The South China Sea Dispute: An International Lawyer's View. Entering Uncharted Waters? Asean and the South China Sea Dispute, ISEAS. Retrieved February 18, 2011, from http://cil.nus.edu.sg/wp/wp-content/uploads/2009/09/Beckman-Paper-on-SCS-Dispute-ISEAS-ASC-18-Feb -2011-final.pdf

Beckman, R. (2013). The UN convention on the law of the sea and the maritime disputes in the south china sea. American Journal of International Law, 107(1), 142-163. http://dx.doi.org/10.5305/amerjintelaw.107.1. 0142

Beckman, R. C., \& Schofield, C. H. (2014). Defining EEZ claims from islands: A potential South China Sea change. International Journal of Marine and Coastal Law, 29(2), 193-243. http://dx.doi.org/10. $1163 / 15718085-12341321$

Chan, I., \& Li, M. (2015). New Chinese Leadership, New Policy in the South China Sea Dispute? Journal of Chinese Political Science, 16. http://dx.doi.org/10.1007/s11366-014-9326-y

Dong, M. N. (2005). Settlement of disputes under the 1982 United Nations Convention on the Law of the Sea: The case of the South China Sea dispute. New York, December 2005. Retrieved from http://www.un.org/depts/los/nippon/unnff_programme_home/fellows_pages/fellows_papers/nguyen_0506_ vietnam.pdf

Franckx, E., \& Benata, M. (2011). Straight Baselines Around Insular Formations Not Constituting An Archipelagic State. Third International Workshop, November 2011. Retrieved from http://www.sudestasiatico.com/public/erik-franckx-marco-benatar.pdf

Fry, J. D., \& Loja, M. H. (2014). The roots of historic title: Non-western pre-colonial normative systems and legal resolution of territorial disputes. Leiden Journal of International Law, 27(3), 727-754. http://dx.doi.org/10.1017/S0922156514000284 
Joyner, C. C. (1999). The Spratly Islands Dispute in the South China Sea: Problems, Policies, and Prospects for Diplomatic. In R. Singh (Ed.), Investigating Confidence Building Measures on the Asia Pacific Region, Report no. 28, Henry L. Stimson Center (1999).

Kim, H. (2013). Baselines under the United Nations Convention on the Law of the Sea: A Critical Analysis. Journal of East Asia and International Law, 6(1), 135-153. http://dx.doi.org/10.14330/jeail.2013.6.1.06

Kuok, L. (2014). Overcoming the Impasse in the South China Sea. Jointly Defining EEZ Claims. East Asia Policy. Paper 4. December 2014. Publisher: The Brookings Institution: Center For East Asia Policy Studies. Washington.

Majumdar, M. (2015). The ASEAN way of conflict management in the South China Sea. Strategic Analysis, 39(1), 73-87. http://dx.doi.org/10.1080/09700161.2014.980545

Myoshi, M. (2012). China's "U-shaped line" claim in the South China Sea: Any validity under international law? Ocean Development and International Law, 43(1), 1-17. http://dx.doi.org/10.1080/00908320.2011.619374

Oude Elferink, A. G. (2001). The Islands in the South China Sea: How Does Their Presence Limit the Extent of the High Seas and the Area and the Maritime Zones of the Mainland Coasts? Ocean Development \& International Law, 32(2), 169-190. http://dx.doi.org/10.1080/00908320151100307

Pharand, D. (2007). The Arctic Waters and the Northwest Passage: A Final Revisit. Ocean Development \& International Law, 38(1-2), 3-69. http://dx.doi.org/10.1080/00908320601071314

Saul, B. (2014). China, Natural Resources, Sovereignty and International Law. Asian Studies Review, 37(2), 196-214. http://dx.doi.org/10.1080/10357823.2013.769497

Song, Y.-H., \& Tønnesson, S. (2013). The Impact of the Law of the Sea Convention on Conflict and Conflict Management in the South China Sea. Ocean Development \& International Law, 44(3), 235-269. http://dx.doi.org/10.1080/00908320.2013.808935

United Nations Convention on the Law of the Sea 1982. Official UN site. Retrieved from http://www.un.org/Depts/los/convention_agreements/texts/unclos/unclos_e.pdf

Westerman, G. (1988). Straight Baselines in International Law: A Call for Reconsideration, 82. Am. Soc'y Int'l L. Proc. 260. Retrieved from http://digitalcommons.pace.edu/lawfaculty/230/

Zou, K. (2005). Law of the Sea in East Asia: issues and prospects (p. 256). Publisher: Routledge. London \& New York.

\section{Copyrights}

Copyright for this article is retained by the author(s), with first publication rights granted to the journal.

This is an open-access article distributed under the terms and conditions of the Creative Commons Attribution license (http://creativecommons.org/licenses/by/3.0/). 